\title{
Lobbying in the United States of America and European Union: A Comparative Approach
}

\author{
Gerti Sqapi, PhD Cand. \\ European University of Tirana, Albania. \\ gerti.sqapi@gmail.com
}

\author{
Doi:10.5901/mjss.2015.v6n2s2p103
}

\begin{abstract}
The aim of this paper is to set in a comparative perspective the development of lobbying in the United States of America and the European Union, taking into account the particular political and institutional structure that characterizes these two areas. Lobbying, as an activity that has had a significant expansion over recent decades, has become increasingly a legitimate part of every democratic system. As such, the legislation of each country has been expanded and adapted to include and regulate such lobbying activities. Per se lobbying is a matter of interest to be studied whether in terms of challenges, opportunities, transparency and potential access it has for influencing the political system of a country. And the two entities that make up more interest to be studied in relation to their properties or characteristics of lobbying are USA and EU. Although the techniques of lobbying in Brussels and in Washington are often regarded as the same, the differences in style and content are still existent between the two areas. The comparative analysis in this paper takes into account institutional differences that exist between the United States of America and European Union; the more strict regulatory approach that leads activities of lobbyists in USA and that less formal in regulating lobbying activities that characterizes the political institutions in the EU; differences that exist in the ways of funding the different lobbying groups; and the differences that exist in the ways of representing diverse interests between these two areas. From such a comparative perspective, this paper will identify the diversities and differences that exist in lobbying between the USA and EU.
\end{abstract}

Keywords: lobbying; interest groups, European Union, USA, lobbying regulation, funding, transparency.

\section{Introduction}

On lobbying - as the process of seeking to influence government and its institutions by informing the public policy agenda (Zetter, 2008: p. 3) - we may say that it is a legitimate part of any democratic system. Although the term in itself carries negative connotations, and is frequently associated with corruptive affairs or unlawful influences of various interests, its legitimacy and importance in influencing the political process in a democratic system are in general accepted. Seen in this perspective, and as a result of the blooming and spreading of the lobbying activities in various policy-making fields during the last decades, the need to regulate the lobbying activities within the legal frameworks is becoming more and more imminent. Such need comes from the fact of securing the necessary transparency and equal opportunities for various lobbying groups to influence a specific policy on one hand, and of guaranteeing the credibility of the political process and the actors involved in it on the other. As such, we could say that lobbying is a matter of interest to be studied in terms of challenges, opportunities, transparency or the potential access it has in influencing the political system of a country. In this paper, two entities will be analyzed in terms of their lobbying specifications or characteristics, the United States of America and European Union; since they are more interesting to be studied in this light.

The aim of this paper is to offer a descriptive study in a comparative approach of the main lobbying characteristics in the USA and EU by focusing on the legal framework of each country (or better, each entity) on the regulation of lobbying activities. Such thing will be carried out by considering as well the institutional, political and historical differences which exist between these two areas on both sides of the Atlantic. The second part of this paper is focused on identifying the particular political and institutional structures which exist in the USA and the EU, by thus providing an overview and by showing the important influence they have on the lobbying natures of each area. The focus on the third part will shift mostly on the legal framework reforms on the regulation of the lobbying activity in the USA and the EU, by thus highlighting the distinctions and differences in lobbying which exist between them.

\section{United States and European Union - Two Separate Political, Institutional and Cultural Environments}

Before examining the separate specifics of the lobbying practices in the USA and the EU, it is important to identify the 
different political and institutional frameworks which characterize these two areas. Naturally, the field or environment where lobbying activities take place is important to be identified and analyzed, because it defines their particular specifics. As Broisched and Coen has shown in this regard, different institutional venues create different political opportunity structures, thus affecting the nature of the lobbying environment they face (Cited in Baumgartner, 2007: p. 484).

In terms of the USA, we could afford to say that it is a nation-state, with a well-defined federal structure which characterizes it and which has been stable for over two centuries. In this regard, the United States can be considered a genuine state, with an institutional frame relatively stable in time (despite the frequent territorial enlargement the US has gone through) under a single Constitution since 1789 when it entered into force. Unlike it, the EU is a system in-themaking that have evolved over the last half century through successive extensions and institutional changes, and therefore "the persistence of the provisional" (Wallace W., 2000: p. 537). In contrast with the USA which has the attributes of a genuine federal state and where sovereignty stands between the national and state governments, the EU is a complex system of supranational institutions with inter-governing features, with decisions which are continuously negotiated by its member states. In other words, "it is an expression of the preference for the "deliberate ambiguity of this semi-confederation" instead of full federation" (Wallace W., 2000, p. 500). The EU is a very complex organization which consists in a mixture of the attributes of a state and those of an international organization [...] and rules and policies are decided and executed by many actors at different levels (Mihut, 2008: p. 7). And, by stressing here that the EU is not a state with genuine attributes which characterize it, but a voluntary political-economic union of 28 different countries that agreed to give up a part of their sovereignty, its institutions (the most important of which are the Council of Ministers, the European Commission and the European Parliament) are often characterized by a tension between inter-governing and supranational features.

From this complex system often referred to as "multi-level governance" within the EU, derives the fact that here, the power, or force, is more disperse, in contrast with the American system where power is more concentrated. (Wallace H., 2000, p. 31). And from this concept, that the EU is not, and should not be considered a genuine state, derives the fact that it has a much more limited jurisdiction or competency compared to that of a state or national government such as the United States of America. While in the USA the sovereignty of national and state governments extends in all policy fields, we cannot say the same about the European Union which has exclusive competencies only in certain policy fields (mainly those related to the Single Market issues and customs union); in other fields, European institutions have only restricted coordinating competencies. This has direct implications in the policy-making process, in the various actors involved in such process, in the legitimacy of various institutions on those involved in lobbying activities, etc. It is also important to mention here the fact that the EU budget is much smaller than the US federal budget, as well as the size of the European institutions administration is much smaller that the American government (Mihut, 2008: p. 8).

Also, another important characteristic which needs to be highlighted before comparing lobbying in the USA and the EU is the different historical and cultural environment which characterizes both sides of the Atlantic in terms of lobbying traditions. Lobbying as a professional activity was created in the United States starting by the end of the $18^{\text {th }}$ century, and since then it has constantly developed and been accepted as a legitimate activity. Different authors (Zetter, 2008: p. 392; Mihut, 2011: p. 65) when referring to the high level of lobbying in the USA and the well- consolidated and legitimate traditions there, refer to, or find the source of it, in the US Constitution Amendment which guarantees US citizens not just freedom of religion, but also freedom of speech, a free press and the right to petition (i.e., lobby) Congress. In such history of development, lobbying in the United States is seen as a legitimate way of representation and advancement of interests from various groups. The contrary can be said about the Europeans, where the lobbying tradition was less developed than in the USA, and which have been skeptical about the legitimacy of lobbying practices as representation channels of various interests. The long American tradition of lobbying means the practice is largely accepted, drawing a wider variety of interest groups - including NGOs and citizen's groups - to fight for the attention of politicians. Europeans are more skeptical towards lobbying as a legitimate part of the political process and have turned to it in fewer, yet growing proportions (Cited in Euroactiv, 2005: p.1-2). And the important lobbying differences between the United States of America and the European Union also derive from this different historical and cultural development.

\section{Distinctions and Differences between the USA and the EU in the Development of Lobbying}

Mainly because of this Madisonian tradition, which has also been sanctioned in the US Constitution, the US has chosen not to restrict the lobbying practice and, generally speaking, the interest groups activities, but to regulate them instead in order to assure more fairness, transparency, and responsibility (Mihut, 2008: p. 5). As a matter of fact, starting from 1946 with "The Federal Regulation of Lobbying Act", which marked the first attempt to regulate lobbying within the legal framework; then with "Lobbying Disclosure Act" of 1995; and the amendments made to the latter through the "Honest 
Leadership and Open Government Act" in 2007, all attempts made in this regard are related to the strengthening of the lobbying activity regulation. In essence, the main objective of these laws was the disclosure of lobbying activities, but gradually they became stronger in terms of directing and regulating the behavior of those involved in the lobbying process as well. Some of the main principles of these acts are: the obligation for the lobbyist to register with the Secretary of the Senate and the Clerk of the House of Representatives; to provide quarterly reports on their activities, and other detailed disclosures; to report who their clients were; what house of the Congress or what agencies they lobbied, how much they were paid; moreover the "Honest Leadership and Open Government Act" of 2007 enhances the disclosure by requiring that campaign fundraising by lobbyist be disclosed to the public and posted on the Internet; establishing a fully searchable and downloadable electronic disclosure database on the Internet; prohibiting gifts and travel by lobbyists and lobbying organizations for lawmakers and congressional staff; and, for the first time, criminal penalties are also provided, namely imprisonment for up to five years or a specified fine, or both (Library of Congress, Thomas 2007; Mihut, 2008: $p$. 12). Thus, in essence, the tendency of the United States to strengthen the regulation on lobbying activities and make them more formal and transparent, without hampering or restricting those who lobby, becomes more obvious.

The regulation of lobbying activities situation in the European Union is different and compared to the United States, more minimal and less formalized standards have been developed. However, it must be highlighted that differences in the regulation of lobbying can be found within the EU institutions themselves, in the European Commission and in the European Parliament, as the two main institutions which undertook initiatives to regulate the lobbying activities, but have also adopted these regulations in various ways. The European Parliament was the first institution within the EU to undertake the initiative of legal proposals for the regulation of the lobbying activities. Thus, through the "Rules of Procedure" approved in 1997, the European Parliament forces its members to adhere the Code of Conduct; while securing to lobbyists access in the Parliament through special passwords, but in exchange requires that lobbyists also to adhere a Code of Conduct and sign a special register. So, the Parliament has adopted an accreditation system for lobbyists, but the register provides only the names of the pass-holders and of the organizations they represent, without giving information about the interests for which the lobbyists act (Mihut, 2011: p. 69).

Meanwhile, the European Commission has been even more open to the consultative process with various interest or lobbying groups, by setting even more minimal rules and standards for them and by relying more on the self-regulation approach. In line with the self-regulation approach of these groups, the Commission launched the "European Transparency Initiative", approved on 23 June 2008 (European Commission, 2008). In essence, the objective of this program was to increase the necessary transparency between the lobbyists and the actors involved in decision-making processes in European institutions, but on the other hand, it makes the registration system voluntary and not binding. European Transparency Initiative set up a voluntary registration for interest representatives coupled with a binding code of conduct (which parties in question must abide by); as an incentive, those who register certain information about themselves will be alerted in return to consultations in their specific area of interest; limited financial disclosure, leaving it up to the registered individuals to disclose their estimated expenditures on lobbying activity, and identify the major sources of their funding (European Commission, 2008; Holman, 2009: p. 280-281). Thus, the European Commission position remains open in this regard, by requesting limited financial disclosure and specific items of their budget sources from the registered individuals, without forcing them into a full mandatory financial disclosure.

Other differences or distinctions in terms of lobbying ways exist between the United States and the European Union beyond these different approaches of lobbying regulations in institutional and legal terms. An important distinction which separates them is the way various interest (lobbying) groups are financed, or the flow towards which the money is headed to. In the USA, various corporations continuously support the electoral campaigns of politicians through the Political Action Committees. "Although the practice is regulated and the sums capped, corporate funding of politics is still a central element in US political life. Such practices are not recognized or regulated in the EU and are generally seen as unethical. In Europe, money has a bigger tendency to flow the other way, from the public sector to civil society in the form of state aids, grants, subsidies and contracts" (Cited in Euroactiv, 2005: p. 2). This way of collecting money and financing of the electoral campaigns is certainly a major difference, because it has stronger and more direct implications in the relations between lobbyists and the elected politicians. This explains in a way why lobbying in the USA is more professional and aggressive than anywhere else. As Nick DeLuca has noted, "establishing oneself as a prodigious fundraiser is a sure way to get noticed on staff radar screens and is the first big step towards winning friends and then most importantly - gaining access" (Cited in Zetter, 2008: p. 386). In contrast with the USA, in Europe such practice of collecting and spending the money from various interest groups (such as in the case of Political Action Committees) for electoral campaign of politicians is not known, and not developed either. It is different in the USA, where the candidates run for positions in the House of Representatives, the Senate or for President, and who need considerable amounts of money for their campaigns; they are always attentive to financial donations made by lobbyists or representatives of 
various businesses or corporations. In a way, it can be said that this represents an endemic relationship between politicians and lobbyists in the USA, because certain donations can make the elected politicians adopt stances on certain policies which favor lobbyists who supported them. And this is important for the USA, if we keep in mind that the key to achieve an effective lobbying here is gaining access though through political relationships and through financial support.

Another factor which implies specific differentiations, maybe not of a lesser importance, is related to the pluralist (or even individualist) dichotomy of interest representation in the USA, and that characterizing Europe which is of a more corporatist nature. As Vogel (1996) stressed, unlike the European countries, where the consultation of companies by the government is assumed, the American companies must invest substantial resources, mostly in lobbying, if they wish to affect public policy decisions, as they do not benefit by the official channels to communicate their positions to public officials (Cited in Mihut, 2008: p. 10). Similarly, even within the EU, the European Commission as the main policy entrepreneur through the right of legislative and consultative initiative, bases its policy-making process mostly on the inclusion of various interests and deliberative trust. As Mahoney has noted, EU policymaking leads to more compromise with all parties achieving some level of success while the U.S. policymaking system tends toward winner-take-all outcomes (Mahoney, 2007: p. 44). This is an important factor which has its implications in the policy-making processes, and also explains the various approaches to lobbying which exist between the US and the EU. In Europe, the corporatist tradition of interest representation continues to remain strong and this is also reflected in a large number of business associations federated into a European level to defend their positions; in the US such interest representation is made on more individualist basis from various interest groups or corporations. If, on one hand (in Europe) social dialogue is an important channel for communication between trade unions, employers' associations and public officials; on the contrary, the lack of official channels through which organizations can influence policy-making in the US explains why substantial resources are spent on lobbying and strict regulations for it are enforced (Mihut, 2008: p. 14-15).

Another reason which marks a distinction in the different approaches to lobbying which exist between the two countries is related to the representation system or the way how representatives in the Parliament are elected. The more pluralist and democratic American system (of course, this is also influenced by the fact that this is a national Parliament and not one which represents multi-national interests of 28 different countries) makes candidates who seek to be elected in Congress particularly attentive to the demands of their electros, regardless of where they come from. While the members of the European Parliament are elected, in most countries, through a system of proportional representation defined at the national level; once elected, they are focused on the European agenda and are trying, sometimes quite hard, to make the national agenda consistent with it (Mihut, 2008: p. 8). Thus, we could say here that the Members of the European Parliament are more detached from their electorate. Also, the lack of knowledge about the Brussels policies in general, the high complexity of issues in question here, and the higher level of difficulty in the way decisions are made (where consensus in a European level between a multitude of institutions and actors, with community and national interests which frequently clash with each-other, is continuously sought); all of these, in general, increase the perception of a greater distancing between the elected MEPs and their electorate, by thus making the EU representation level less readable and deportable. Exactly the contrary could be said about the same situation in the US Congress, where members of House of Representatives and senators are more cautious and attentive to the voices and demands of their electorate, thus also becoming easier targets. For this reason, a good lobbying strategy in this case, would be related to securing the support of voters who support your proposals. The best lobbyists know that members of Congress will meet with their voters and respond to the ideas and concerns coming from their district (Zetter, 2008: p. 382). In the MEPs case, the different way of being elected and the largest distance which exists between them and their voters, makes them less attractive to the eyes of lobbyists who could direct their energy and resources on them.

Perhaps another reason to be mentioned which explains to a certain point why lobbying which exists in the USA is more sophisticated and aggressive compared to the one developed in the EU, is related to the considerable amount of money spent and allocated in the annual budget by the government in Washington. In the financial year 2007-8, the total US federal Budget was $\$ 2.66$ trillion (without taking in consideration here the expenses of particular states)... and you have a truly staggering amount of money up for grabs (Zetter, 2008: p. 395). And this represents a reason not so inconsiderate for whoever involved in a "war" with others by using all means or tools to benefit from them. While such a thing cannot be said in the case of the EU budget - although its population is double that of the US - in 2007 it had an annual budget which did not exceed €130 billion. Put differently, this budget represents just over $1.2 \%$ of the GDP of the member states - and the Budget is not allowed to exceed 1.24\% (Zetter, 2008: p. 349). Thus, the pieces of "cake" one could get, are smaller here, and the budgeting process itself is more complicated given that we are dealing with a multitude of various institutions and actors, and various interests which frequently clash between them. 


\section{Conclusions}

In conclusion, we could say that, although lobbying tactics or ways implemented in the USA and the EU are often considered the same - and considering that lobbying is mainly a Western democratic tradition - distinctions or differences in lobbying continue to exist between the two countries. These differences in lobbying between the two countries are first of all related to the different historical, cultural and political environment which characterizes both sides of the Atlantic. Also, another important factor which was mentioned here is related to the long and legitimate lobbying tradition in the US as compared to that in Europe, where it is seen with skepticism. Perhaps, the biggest difference of lobbying between the USA and the EU is related to the different regulation approaches from a legal and institutional point of view. If in the USA, the first attempts in this regard were more and more related to the strengthening of lobbying activity regulation, and by making their registration binding; in the EU, the approach adopted mostly (from the European Commission) was that of self-regulation. However, during the recent years, e attempts to somehow strengthen the regulation on lobbying were made here as well, by making lobbyists observe a Code of Conduct and by requesting their accreditation (as in the case of European Parliament). Other characteristics which separate lobbying between the two countries mentioned here are related to the different financing ways or the flow where money is directed to: from various pressure (lobbying) groups or corporations towards politics as in the case of the USA, and the contrary in Europe, where the money flows mostly from the public sector towards civil society; we also mentioned the different interest representation nature which exists in both countries: more pluralist (and more individualist) in the USA and with interest groups which compete with each-other to gain access or get what they want (which explains why in the US more considerable resources are spent in lobbying than anywhere else), and the somehow corporatist and social nature of these interests representation in Europe. Also, the different representation system (the way representatives are elected) in both countries makes a difference in lobbying between them: US Congress members are more attentive to requests/concerns of their electorate thus becoming easier targets, while MEPs are more detached from their electorate and more focused on the European agenda, which makes lobbying with them difficult. By taking all these in consideration, we could say that there are differences and distinctions in the lobbying made in the USA and the EU.

\section{References}

Baumgartner, Frank R. (2007) "EU Lobbying: A View from the US". Journal of European Public Policy, Vol. 14, No. 3, p. 482-488.

Broscheid, Andreas and Coen, David (2007) "Lobbying activity and fora creation in the EU: empirically exploring the nature of the policy good". Journal of European Public Policy, Vol. 14, No. 3, p. 346-365.

European Commission (2008) "European Transparency Initiative: A Framework for Relations with Interest Representatives" (Register and Code of Conduct), COM (2008) 323, Brussels: European Commission. Available at http://ec.europa.eu/transparency/ docs/323_en.pdf (Last accessed on 05 January 2015).

European Commission (2006) "Green Paper "European Transparency Initiative". COM (03.05.2006) 194 final, Brussels: European Commission. Available at http://europa.eu/documents/comm/green_papers/pdf/com2006_194_en.pdf (Last accessed on 05 January 2015).

Euroactiv (2005) "EU and US approaches to lobbying". Available at http://www.euractiv.com/pa/eu-us-approaches-lobbying/article135509 (Last accessed on 05 January 2005).

Library of Congress Thomas (2007) S.1: "Honest Leadership and Open Government Act". Available at http://www.gpo.gov/fdsys/pkg/ BILLS-110s1enr/pdf/BILLS-110s1enr.pdf (Last accessed on 05 January 2015).

Holman, Craig (2009) "Lobbying Reform in the United States and the European Union: Progress on Two Continents", in Conor McGrath (edt.) "Interest Groups \& Lobbying in United States and Comparative Perspectives: Essays in Ethics, Institutional Pluralism, Regulation, and Management". The Edwin Mellen Press, Lewiston, p. 267-296.

Mahoney, Christine (2007) "Lobbying Success in the United States and the European Union". Journal of Public Policy: Vol. 27, Issue 1, p. 35-56.

Mihut, Liliana (2008) "Lobbying in the United States and the European Union: New Developments in Lobbying Regulation". Romanian Journal of European Affairs: Vol. 8, No. 4, p. 5-17.

Mihut, Liliana (2011) "Lobbying - A Political Communication Tool for Churches and Religious Organization". Journal for the Study of Religious and Ideologies: Vol. 10, No. 29, p. 64-86.

Wallace, Helen (2000) "The Institutional Setting", in Helen Wallace and William Wallace (eds.), "Policy-Making in the European Union", Fourth edition, Oxford: Oxford University Press, pp. 3-37.

Wallace, William. (2000) "Collective Governance", in Helen Wallace and William Wallace (eds.), "Policy-Making in the European Union", Fourth edition, Oxford: Oxford University Press, pp. 523-542.

Zetter, Lionel (2008) "Lobbying: The Art of Political Persuasion". Hampshire: Harrimon House Ltd. 
